\title{
The Marketization of Higher Education Discourse: A Genre Analysis of University Website Homepages in China
}

\author{
Tongtong $\mathrm{ZHANG}^{1}$ \\ ${ }^{1}$ International College, Guangdong University of Foreign Studies, Guangzhou, China \\ Correspondence: Tongtong ZHANG, International College, Guangdong University of Foreign Studies, Higher \\ Education Mega Center, Panyu District, Guangzhou City, Guangdong Province, 510006, China. E-mail: \\ 200820426@oamail.gdufs.edu.cn
}

Received: July 13, 2017

doi:10.5539/hes.v7n3p64
Accepted: July 17, 2017

Online Published: July 27, 2017

URL: http://doi.org/10.5539/hes.v7n3p64

\begin{abstract}
The past three decades have witnessed the growing influence of market forces on higher education, resulting in what is defined by Fairclough (1993) as the marketization of academic discourse. The present study attempts to examine the effect of such trend on university website homepages in China, which is an under-researched genre of higher education discourse. By applying the Critical Discourse Analysis (CDA) and genre analytical approach, this article describes the generic characteristics of the "About Us" section in five university website homepages, analyzing the structural organization, rhetorical moves, communicative purposes as well as the discursive strategies used in the text. Research shows that authoritative discourse forms the key note in this genre, a reflection of the centralized operation of Chinese universities. Meanwhile, the existence of conversational discourse reveals the university's endeavor to establish a friendly relationship with the prospective students. Furthermore, promotional elements in terms of both contents and linguistic choices have been employed to help construct a positive image of universities to stand out in the stiff competition in today's higher education market in China.
\end{abstract}

Keywords: marketization, higher education, discourse analysis, genre analysis, Chinese universities, website homepages

\section{Introduction}

\subsection{Marketization Process in Higher Education}

The civil mission of higher education used to be the cultivation of great thinkers, the promotion of human development as well as the creation of non-utilitarian knowledge (Askehave, 2007; Kwong, 2000). Admission to the prestigious public universities was "by invitation only", bringing with them a "promotion value" without having to actually promote themselves (Wernick, 1991). Higher education had remained largely insulated from the market influence until the past decades, when globalization has brought about overwhelming changes to all arenas of society, including the educational sector. Under the pressure of curtailment in state funding worldwide as well as both national and international competition, universities are forced to exploit different means of financial support (Askehave, 2007; Osman, 2008; Mok, 1999, 2000), such as attracting fee-paying students, competing for research grants and developing marketable "products" (Askehave, 2007). It was under such circumstances that the marketization process in higher education took place across the globe, when universities started to transform into "corporate universities" (Jarvis, 2001) and become business-like entities (Connell \& Galasinski, 1998). As Kwong defines, "marketization in education refers to the adoption of free market practices in running schools. These include the business practices of cutting production cost, abandoning goods not in demand, producing only popular products, and advertising products to increase sales and the profit margin" (Kwong, 2000, p. 89).

Many countries have embraced the ideas of "corporate management" and employed various ways to cope with such trend. In the UK, for instance, universities have adopted market and managerial principles, introduced competition as well as provided more choices to the students, alongside raising funds from industries and obtaining sponsorship for activities (Mok, 1999). Similarly, higher education in the US is also markedly affected by the marketization process, with a view to the introduction of competition in education and the adoption of a 
"customer-oriented" approach including measures such as "Total Quality Management" and "Employee Involvement" to ensure service quality in both the public and private sectors (Brown, 1995).

In China, the marketization process in education started in line with the economic reform from 1978, when the central government initiated a decentralization policy in both the economic and educational realm. For a long time, Chinese universities have been perceived as the ivory towers free of the "force of mass culture and industrialization" (Symes, 1996, p. 133). Nevertheless, since 1978, Chinese educational services have been significantly reshaped by the globalized marketization process, integrating diversified corporate practices into the running of higher education institutions. Mok (2000) outlines five characteristics of higher education marketization in China, namely (a) adopting a fee-charging principle; (b) diversifying educational services by the private sector; (c) creating market-driven courses; (d) organizing revenue-generation activities; and (e) introducing internal competition. Additionally, China's entry into the WTO and the signing of "General Agreement on Trade in Services (GATS)" have brought in even fiercer competition to the internationalization of higher education and accelerated the process of marketization in China.

\subsection{Marketization Manifestation in Higher Education Discourse}

In order to project a positive image to stand out in competition, universities have eagerly adopted corporate advertising strategies to rebrand themselves to attract public attention. As Bhatia (2005) suggests, "of all the genres which have invaded the territorial integrity of most professional and academic genres, 'advertising' clearly stands out to be the most prominent instrument of colonization" (quoted in Kong, 2006, p. 775). A prime example of this phenomenon is the use of promotional discourse in higher educational sector. Terms from the corporate world such as "customers", "clients", "markets", "corporate identity", "mission statement" and "strategic plans" began to appear in higher education discursive practices (Connell \& Galasinski, 1998; Askehave, 2007; Mok, 1999). Promotional elements exemplified by the lexical, grammatical and syntactic choices are present and prevalent in various genres of higher education discourse such as brochures, prospectuses, flyers, posters, job advertisements and home pages on websites (Fairclough, 1993, 1995; Askehave, 2007; Osman, 2008). These genres of higher education discourse have shifted the emphasis from simply providing information about university programs and underlining requirements and obligations to promoting their selling points and persuading potential applicants to choose the university. While Fairclough refers to such genres as "new hybrid partly promotional genres" (1993, p. 139), Askehave contends that they have become "fully (original italic) promotional texts in their own right", not trying to hide their primary intention of attracting fee-paying students to choose the university (2007, p. 725).

In view of this, the present study sets out to investigate the effect of marketization on higher education discourse in China, with particular reference to the genre of university website homepages, which at present are hugely under-researched. The study is primarily a genre analysis of the text structure, rhetorical moves, communicative functions and discursive strategies of the "About Us" section in the homepage, with a particular focus on how social contexts and market forces have influenced the use of language from the Critical Discourse Analysis (CDA) perspective. Before a detailed analysis is conducted, I will first review relevant literature on higher education discourse, particularly on the genre of university website homepages as well as outline the analytical approaches and procedures in the following two parts.

\section{Literature Review}

\subsection{Previous Studies on Marketization in Higher Education Discourse}

As early as in 1993, Fairclough detected the presentation of marketization in texts for both external and internal communication of UK universities and claimed that the discursive practices of higher education were "in the process of being transformed through the increasing salience within higher education of promotion as a communicative function" (1993, p. 143). He compared the 1967-1968 entry in an undergraduate prospectus with the 1993 entry and concluded that "the 1966-1967 entry gives information about what is provided on a take-it-or-leave-it basis. In the 1993 prospectus by contrast the promotional function is primary; it is designed to 'sell' the university and its courses to potential applicants in the context of a competitive market" (1995, p. 156). Fairclough's pioneering works $(1993,1995)$ successfully drew researchers' attention to this field and inspired parallel studies on various higher education genres. For instance, Connell and Galasinski analyzed the mission statements of 146 higher educational institutions in the UK in the late 1990s. By examining the structures, grammar and vocabulary, they found that the academic mission statements "both acknowledged and (original italic) negotiated the political-ideological context" and some universities "made lexical concessions to what may be regarded as commercial discourses" (1998, p. 476). Another prominent study on higher education discourse was conducted by Askehave (2007), who investigated the generic characteristics of four international student 
prospectuses from Australia, Finland, Japan and Scotland from the CDA perspective. By using a text-driven procedure for genre analysis proposed by Askehave and Swales (2001), she identified the overall structure, content and rhetorical moves of these prospectuses, echoing with Fairclough's findings that "institutions of higher education come increasingly to operate as if they were ordinary business competing to sell their products to consumers" (1993, p. 143). Askehave further highlights that the provision of an interesting and challenging university "experience" to satisfy the picky students who is "spoiled by choice" is an equally important selling point as the programs offered (2007, p. 739). Like Askehave, Osman (2008) also uses a genre analysis to study the brochures as a promotional genre from 11 Malaysian public universities and discusses the way in which corporate advertising strategies were employed to realize the communicative functions of the brochures. She refers to these strategies as "rebranding" strategies as they help to change the traditional image of the public universities in Malaysia to become more "market-oriented", "competitive" and to function like corporations (2008, p. 70).

Researches into higher education discourse in China are quite a recent phenomenon. Xiong (2012) conducts an investigation into the effects of marketization and promotional culture on higher education, taking the genre of advertisements for academic posts as a case study. His findings resonate with the previous studies in that various discursive strategies contribute to the realization of the promotional purposes of higher education genre. It is noteworthy that he expands the boundary of studies in Chinese scenario by claiming the necessity to understand the issue in the light of a "bureaucracy-market alliance", given the distinctive characteristics of Chinese cultural and political context $(2012$, p. 332). Han (2014) also probes into the issue of how and to what extent marketization has invaded the discourse of Chinese universities. In his study, the case of university graduation ceremonies is brought into the spotlight, with a special focus on the texts of university presidents' parting speeches. Han's study is conducive to the understanding of Chinese higher education discourse, as he not only enriches the genre study in Chinese context, but more importantly, points out that the "conversationalized" speeches reflect presidents' rhetorical strategies to strike a balance between maintaining "Chinese centralized and instrumental operation of universities" and the challenges of their "increasingly marketized identity and academic restructuring" (2014, p. 100).

The aforementioned studies invariably point to the fact that the values and logics of marketization have penetrated into higher education discourse, due to the need for higher education institutions to respond to the strong market forces. Furthermore, such investigations into higher education discourse touch upon a wide spectrum of genres including prospectuses, brochures, mission statements, academic job advertisements, presidents' parting speeches, etc.

\subsection{Researches into University Website Homepages}

Nevertheless, there is still one genre of higher education discourse that is pretty much neglected and thus under-researched: university website homepages. With the ubiquity of the internet, universities worldwide have in the past decades established and improved their websites as an indispensable tool to provide information, present themselves to the public and promote their identities and missions (Zhang \& O'Halloran, 2012, p. 88). Specifically, the homepage plays a central role in shaping a university's identity, introducing its mission, and appealing to prospective students in face with the competitive marketization of higher education in the globalized age (Fletcher, 2006). Consequently, to study the discourse of university homepage leads to a deeper understanding of how universities brand themselves and function as institutions (Zhang \& O'Halloran, 2012, p. $88)$.

So far, researches into university website homepages mostly fit into the category of multimodal investigation, with Zhang and O'Halloran's study (2012) as a typical example. They explore how semiotic resources are deployed in two university homepages as hypermodal discourse to create an official gateway and an institutional identity at the same time. They also discover the effect of marketization on the different hypermodal choices in the homepages, arguing that the National University of Singapore's homepage is much more promotional than Tsinghua University's, which remains in a "powerful gate keeper role" (2012, p. 106). Other studies of university website homepages in China seem to have followed Zhang and O'Halloran's footstep in the use of multimodal analysis. For example, Wang (2016) carries out a multimodal discourse analysis on the homepages of Stanford University and Tsinghua University and uncovers the differences of the two homepages in deploying two semiotic resources to represent principal institutional participants.

As is clear from the above studies, researches into the marketization of higher education discourse in China still lag behind, compared with those from western countries. Therefore, it is imperative for us to push forward our study in this field to keep abreast of the overwhelming trend of marketization in higher education. Furthermore, 
there is a huge potential to tap in the study of university website homepages from the perspective of genre analysis, since current studies on this genre are far from adequate and very much restricted to multimodal analysis. Such considerations have added to the significance of the present study, which will closely examine university website homepages, a neglected higher education genre, in the new light of a genre analysis as opposed to a multimodal one.

\section{Methodology}

\subsection{Analytical Approaches}

A genre-analytical method proposed by Bhatia (1993) and Swales (1990) will be applied in the current study. Genre is defined by Swales as "a class of communicative events, which share some set of communicative purposes" (1990, p. 58) whereas Bhatia (1993) also notes that a shared set of communicative purposes is the most important factor in genre identification. Thus the first issue to be addressed is to find out the communicative purposes of university website homepages identified as a genre. Meanwhile, rhetorical moves are also central to genre analysis. Again, Bhatia (1993) and Swales give similar definition that a move is a kind of "cognitive structuring" or "discoursal or rhetorical unit" that serves "a coherent communicative function" (2004, p. 228). In view of this, the move structure or the text organization of this genre will be studied and the obligatory moves and optional moves will be sub-divided. By employing this method, the generic characteristics including text structure, rhetorical moves, and communicative purposes will be identified and summarized. Another crucial aspect is to examine what discursive strategies have been adopted to fulfill the communicative purposes of the rhetorical moves.

Moreover, the CDA paradigm also has a crucial role to play in this study. Fairclough views language "as a form of social practice" (2001, p. 18) and "a socially and historically situated mode of action" (1993, p. 134). In this sense, genre as a typical form of utterances should be studied in its social contexts (Berkenkotter \& Huchin, 1993). The three stages of CDA (the description of text, the interpretation of the relationship between text and social context, as well as the explanation of the relationship between interaction and social context) provide us with a sociolinguistic perspective about the effect of marketization on university website homepages. This method enables us to understand the issue from a broader and more comprehensive point of view by factoring in the social, cultural, economic, and political influences as well as their manifestation in the discursive strategies.

\subsection{Research Questions}

In the text analysis, we have specially chosen the "About Us"/"About*" (acronym of university name) section of the homepage to be the focus of our study. This section is an essential component found in virtually all university website homepages, which gives an overview about the university as well as some fast facts such as history, administration, anthem, logo, etc. Since it is probably the first section that most visitors will click on, it constitutes the most representative part in the homepage, fully demonstrating the distinctive generic characteristics of homepage as well as the unique identity of each university. Therefore, it is justifiable to limit our study to this section.

Our corpus consists of texts of the "About Us" section from five universities in China: Tsinghua University (THU), Fudan University (FDU), Shanghai Jiaotong University (SJTU), Zhejiang University (ZJU) and Nanjing University (NJU). These five universities are singled out from the top 120 universities from the QS World University Rankings 2018, which include seven Chinese universities. They ranked $25^{\text {th }}, 40^{\text {th }}, 62^{\text {nd }}, 87^{\text {th }}$ and $114^{\text {th }}$ respectively. Another reason for choosing these five universities is that they all have well-established websites and the texts of the "About Us" section are well written, which lend themselves to text analysis.

We will conduct an in-depth investigation into the effect of marketization on these five university website homepages, guided by four research questions:

1) What are the text structure, rhetorical moves and communicative purposes of the "About Us" section in these universities?

2) What discursive strategies in terms of lexical, grammatical and syntactic choices are adopted to achieve these communicative purposes?

3) To what extent has the marketization trend influenced this genre in the five cases?

4) How are the social relationships between the university and the students created by the text? 


\section{Analysis}

A close scrutiny of the "About Us" section in the five university website homepages reveals that there are 11 identifiable sub-sections, ranging from "President's message" to "Contact Us", each of which is designated a "move" (seven in total), such as "Welcoming" and "Soliciting Responses". While two of the moves, namely establishing credentials and describing administration are obligatory and contained by all university websites, the rest five are optional, meaning that they are present in some homepages but absent in others. This part of information is indicated in Table 1.

Table 1. Structural organization of the "About Us" section

\begin{tabular}{lll}
\hline Move & Sub-section title & Obligatory/Optional \\
\hline Welcoming & President's message & Optional \\
Establishing credentials & Overview & Obligatory \\
& History & \\
& Facts \& figures/Statistics & \\
& Publications & Obligatory \\
Describing administration & Leadership & Optional \\
Attracting attention & University logo, motto, song, & \\
Offering extra services & and video & Optional \\
Locating the service & Facilities available & \\
Soliciting responses & Visiting the campus & Optional \\
\hline
\end{tabular}

Note. The term "service" in the table refers to both the educational and support services offered by the university.

It is noteworthy that different sub-sections can be designated the same move. For instance, "Overview" and "History" are both identified as "Establishing credentials" whereas "Facilities available" and "International student services" are legitimately assigned the move of "Offering extra services". Moreover, it is also necessary for us to unveil the individual variation in the choice and sequence of moves in the five cases, as is shown in Table 2.

Table 2. Move structure of the "About Us" section in five university website homepages

\begin{tabular}{lll}
\hline University & Move & Sub-section title \\
\hline THU & Establishing credentials & Overview \\
& & History of Tsinghua \\
& Welcoming & Statistics \\
& Describing administration & Message from the President \\
& & Current Administrators \\
FDU & Describing administration & Leadership \\
& Establishing credentials & \\
& & History (Overview included) \\
& Attracting attention & Facts \& Figures \\
& Locating the service/Soliciting & Identity \\
& Visiting Fudan \\
\hline
\end{tabular}




\begin{tabular}{|c|c|c|}
\hline \multirow[t]{11}{*}{ SJTU } & Establishing credentials & Overview (History included) \\
\hline & & Facts and Figures \\
\hline & & President's Welcome \\
\hline & Welcoming & SJTU Today (Video) \\
\hline & Attracting attention & International Student Services \\
\hline & Offering extra services & Life@SJTU \\
\hline & & Library \\
\hline & & Museums \\
\hline & & Administration \\
\hline & & Administrative Departments \\
\hline & Describing administration & Contact Us \\
\hline & Soliciting responses & \\
\hline \multirow[t]{10}{*}{ ZJU } & Establishing credentials & Overview \\
\hline & & Facts and Statistics \\
\hline & & ZJU's History \\
\hline & & ZJU-Wide \\
\hline & & Publications (Journals) \\
\hline & Welcoming & A Message from the President \\
\hline & & Administration \\
\hline & Describing administration & \\
\hline & Locating the service & $\begin{array}{l}\text { Visiting, touring and getting } \\
\text { around ZJU }\end{array}$ \\
\hline & & Hangzhou \\
\hline \multirow[t]{6}{*}{ NJU } & Welcoming & Message from the President \\
\hline & & University Motto and Spirit \\
\hline & Attracting attention & NJU at a Glance \\
\hline & & By the Numbers \\
\hline & Establishing credentials & Leadership and Administration \\
\hline & Describing administration & \\
\hline
\end{tabular}

Despite the use of different words in the sub-section titles, it is easily understood that "Leadership" and "Administration" as well as "Facts \& figures" and "Statistics" actually contain the same contents. It is also interesting to note that the "About Us" section of SJTU website has the most sub-sections, totaling 11, followed by that of ZJU website, with 8 sub-sections. Meanwhile, although THU, FDU and NJU have the same number of sub-sections (5), their moves are not exactly the same.

The following part is a detailed analysis of the communicative purposes of different rhetorical moves, the discursive strategies used, the traces of marketization influence in the texts as well as the relationship between the university and the students.

\subsection{Welcoming}

Except for FDU, all other four universities have a welcoming message/remark from their President placed in the first or second position in the "About Us" section, signifying its importance. Although it is not an obligatory move, welcoming remark is gaining popularity and has been included in a growing number of university website homepages in China recently. The purpose of this move is to communicate the university's friendly and 
welcoming attitude to the readers, thus helping to build the first contact between the university and the potential students.

A close examination of the welcoming remarks by the four university presidents reveals that they are rather identical, both in terms of contents and discursive strategies. Firstly, they invariably contain the mission of education, the strength of university as well as the goodwill to welcome the students. These three components characterize the structure of the welcoming remark as a sub-genre. With respect to discursive strategies, authoritative discourse and conversational discourse coexist. As Xiong rightly points out, although China has followed the trend of marketization in higher education, Chinese situation has to be understood from the angle of "a close-knit economic-bureaucratic relationship" (2012, p. 331). Specifically, Chinese authorities still prefer to maintain the universities' instrumental nature of serving the national interests ( $\mathrm{Li}, 1990)$. Moreover, the president as the hierarchical authority shoulders the responsibilities of assuring the students' compliance with national ideologies and obedience to the teachers (Han, 2014). Consequently, authoritative/bureaucratic discourse is mostly used in the president's welcoming remark, which can be exemplified by various discursive practices including the use of third-person subject, ideological education and quotation of top leaders, as are shown in the following extracts.

\section{A. third-person subject}

- $\quad \underline{\text { SJTU }}$ took first-class talents education as its principal mission.

- Zhejiang University is a place of tradition.

- $\quad$ Nanjing University has seized this historic opportunity and gained vitality.

Except for THU, presidents of the other three universities constantly use the university name as the subject in virtually all sentences throughout the remark, leading to a kind of "authorless discourse" (Connell \& Galasinski, 1998). Readers are distanced from the university by the impersonal description and cannot develop any emotional attachment to the university. It is also noticeable that Shanghai Jiaotong University uses its acronym most of the time, as in the sentence "SJTU, as it is fondly called", which shortens the distance between the university and the students to some extent.

B. ideological education

- $\quad .$. talents with a diverse variety of skills that meet the needs of our country and people. (THU)

- $\quad$... bearing the responsibility of invigorating the Chinese nation. (SJTU)

- $\quad$... translating knowledge and creativity to benefit the people in our country. (ZJU)

- Nanjing University makes significant contributions to the revitalization of China.

As can be seen, ideological education centering on teaching students to serve the country and the people is detected in the welcoming remarks in all four universities, evidence of the moralizing element in authoritative discourse as well as the instrumental nature of Chinese universities. It is noteworthy that NJU's president uses expressions associated with ideological education most frequently, in five different places in total, demonstrating a relatively high degree of authoritativeness.

C. quotation of top leaders

- $\quad$ CPC General Secretary Xi Jinping sent a congratulatory letter to Tsinghua, praised Tsinghua for its fine traditions...

- ...carry out the instruction of "the First Nanjing University" proposed by President Xi Jinping.

The quotation of top leaders' remarks reflects the university's commitment to the country's policy and loyalty to the government's leadership, indicative of the centralized operation of Chinese universities. On the contrary, conversational discourse which is fundamentally from the authoritative one also exists in the president's remarks. Fairclough contends that conversationalization is of the most striking trend of the discursive changes affected by the commodification of social practices $(1992$, p. 202). On the one hand, conversationalization refers to "the simulation of private, face-to-face, person-to-person discourse in public mass-audience discourse-print, radio, television" (Fairclough, 1995, p. 80); on the other hand, it connotes that there is a growing equality between professionals/bureaucracies and clients/citizens when the latter has transformed from passive information receivers to active communication participants. Such discourse is represented by a number of rhetorical practices, including the use of first-person/second-person pronoun, expressions of solidarity and gratitude. 


\section{A. first-person/second-person pronoun}

- To be more innovative, we have high priority to cultivating innovative talents. (THU)

- I would like to extend my cordial greetings and best wishes to our students. (THU)

- $\quad$ You are always welcome to visit us on campus. (SJTU)

- I feel honored and proud to be part of the legacy and tradition of the university. (ZJU)

As is mentioned above, university names are used as the subjects in SJTU, ZJU and NJU whereas in THU, the first-person pronoun "we" is used in most cases. Here, "we" is a collective identity, including the president, the faculty members as well as the university as an institution. As a matter of fact, the practice of portraying service providers as a team involving a group of people is prevalent in advertising, when the speaker stands for the corporation and speaks with a corporate voice (Muhlhausler \& Harre, 1990, pp. 175-176). Admittedly, the personalization of the university has successfully bridged the gap between the universities and the prospective students. In the same way, the discursive practices of the president referring to himself as "I" and the students being addressed as "you" place the two parties on equal position of communication. By speaking out his personal voice, the president lowers his status and treats the students as if they were his friends, thus forming an intimate relationship between them.

B. expressions of solidarity

- $\quad \ldots$ as well as Tsinghua alumni at home and abroad.

- ... with the concerted efforts of our faculty, staff and students... (THU)

- ... deeply rooted in the hearts of its alumni... (SJTU)

- $\quad$... to work with all of you for a more promising future. (ZJU)

- Let's work together for a better future! (NJU)

The conversational discourse also represents itself by the above expressions of solidarity. Phrases like "work with", "the concerted efforts" and "work together" reflect the president's and the university's willingness to establish a broad unity among all stakeholders. Such expressions are able to strike a chord in the heart of the readers with the university and create a sense of belongingness. Moreover, the word "alumni" consolidates the emotional bonds between the university and the graduates, further contributing to the portrayal of the strong connections between the two sides.

\section{C. expressions of gratitude}

- I also offer my heartfelt gratitude to all friends for their unfailing support to Tsinghua over the years. (THU)

- Thanks for your interest in SJTU.

- We thank you for your attention and look forward to your arrival! (NJU)

The presidents use the above "face-redressing politeness strategies" to elevate the position of the readers and ease the "asymmetry" between the university and the readers (Xiong, 2012, p. 331). Upon this moment, the president has more or less abandoned his supremacy and exhibited the maximal courtesy to the readers, best illustrating the conversationalized element in the welcoming remark.

\subsection{Establishing Credentials}

Establishing credentials is reported to be a crucial component in promotional genres (Bhatia, 1993). In advertising discourse, a great deal of writing tries to convince the readers that they have a problem or demand, and the product or service provided "is not just a solution but also the best solution" (Jordon, 1986, p. 36). By establishing credentials, corporations are more likely to persuade the readers to buy their (original italic) products or services. In the context of higher education discourse, this move not only informs the readers the strength of the universities, such as the reputation and achievements, but also helps to promote the universities' Unique Selling Points (USPs), "the kernel of the sales message" (Leech, 1966, p. 36).

In the current study, the EC move is split into four sub-moves: overview, history, facts \& figures/statistics and publications. The first three sub-moves are obligatory and contained in all five university websites, whilst "publications" is exclusively contained in that of ZJU. Similar to the welcoming move, there is a mix of authoritative/authorless discourse which offers impersonal description of the university and a marketized discourse which emphasizes on "selling" and "promoting" the universities, the latter of which will be the focus of the following analysis. 


\subsubsection{Overview and History}

These two sub-moves have many commonalities and are thus put in the same category. In fact, they are sometimes overlapping since there is usually a brief account of the university's history in the overview. Three discursive strategies have been spotted in these two sub-moves to achieve the communicative purpose of promoting the university: using qualitative terms, stating administrative status and highlighting internationalization.

\section{A. using qualitative terms}

- Tsinghua University has developed at a breathtaking pace into a comprehensive research university.

- SJTU has become a comprehensive, research-oriented, and internationalized top university in China.

- $\quad . .$. it progressively established an objective to build a world-class university. (FDU)

- Zhejiang University is a prestigious institution of higher education with a long history and was one of the earliest modern academies of higher learning.

- NJU has been among the most active universities and will strive to make itself into a first-class university around the world.

Obviously, abundant qualitative terms such as evaluative adjectives and superlative forms have been employed to highlight the universities' credentials in the aspect of history, education, research, etc. These expressions are more promotional than informational in that they not only present information to the public, but more importantly, try to convince the public about the quality of the universities. These terms can construct a positive and vivid image in the readers' mind, leaving a good impression on them. Additionally, the use of different adjectives showcases the USPs of each university. For example, while SJTU prefers to stress its "internationalized" characteristic, ZJU is inclined to portray itself as one of the "earliest" institutions, so that each university is more recognizable in the competitive market.

\section{B. stating administrative status}

Another distinctive generic characteristic of these sub-moves is the reference to administrative status of the university, as is shown in the following extracts.

- $\quad .$. is a key university directly under the administration of the Ministry of Education (MOE) of the People's Republic of China and co-constructed by MOE and Shanghai Municipal Government. (SJTU)

- ... a preliminary hearing of the National Ministry of Education's "Plan 211" division proposed a blueprint for building Fudan University ...

- Zhejiang University is under the direct administration of China's Ministry of Education, with joint support from both the Ministry of Education and Zhejiang Provincial Government.

- $\quad$ NJU was accredited as a key university receiving support by "211 Project"... receiving support by "985 Project"... under the joint construction by the Ministry of Education and Jiangsu Province.

The above lexical and grammatical devices describe the social status and high profile of these universities. Firstly, the "211 Project" and "985 Project" single out the top 100 institutions in China, attach strategic importance to them and build them to become world class universities in the early $21^{\text {st }}$ century (Mok, 1999). As a result, the two projects bestow an honor to these universities as they are qualified to be included as top universities. Secondly, universities "under the direct administration of MOE" are granted with "more resources and favorable treatment from the government", since Chinese universities are operating in a "quasi-bureaucratic system modeled on the government" (Xiong, 2012, p. 328). On the other hand, better employment and higher salaries are also guaranteed to the graduates from these universities, which is another USP that attracts potential students to choose the universities. These discursive strategies reflect the symbiotic relationship between bureaucracy and marketization in Chinese higher education.

C. highlighting internationalization

- To become more international, we have pursued deeper international cooperation in all areas to help our students gain international perspectives and better connect China to the world. (THU)

- Today this centennial university is sailing for the aim of becoming a comprehensive, research-oriented and internationalized world-class university. (SJTU)

- ... a wide range of international exchanges create favorable conditions for students' development. (ZJU) 
- NJU is vigorously promoting international communication and cooperation ... raising its teaching to the international standards in every aspect.

As is clear from the above examples, the word "international" or "internationalized" appears more than once in the texts of overview and history in each of the four universities (except for FDU). It describes a wide spectrum of arenas where international cooperation takes place including "teaching programs, partnerships, students and staff exchanges" (Ayoubi \& Massoud, 2007, p. 329). In the globalized market, internationalization has become a new trend in higher education and as well a good strategy for boosting market profile and international image (Mazzarol, 1998), since it offers students chances to gain professional knowledge and cross-cultural experience simultaneously (Brown, 1997). Such discursive strategy displays the universities' response to the market trend and contributes to the establishment of university credentials in the new era.

\subsubsection{Facts \& Figures/Statistics}

This sub-move is obligatory and included in all five university websites. Except for NJU where figures are presented with pictures, statistics are generally presented in the form of table, with a list of important numbers from six categories: students, faculty, schools, programs, research and facilities (including hospitals, libraries, campus space, etc.). A careful comparison of this sub-move indicates that there are both similarities and differences regarding content and linguistic choice. In terms of similarities, the three "core" components contained in all university websites are: student, faculty and programs. It is also interesting to see that the number of international students is cited in all of them, another representation of internationalization in higher education discourse. Also noteworthy is the fact that all universities are inclined to mention the faculty's professional titles conferred by MOE such as the State "1000-elite Program" Experts and "Cheung Kong Scholar's Program". As regard differences, four universities except THU list the number of research centers and national key labs. Moreover, NJU also lists the rankings in four different fields and THU, FDU and ZJU list the number of their supporting facilities.

It has long been held as a tradition in China that people use quantitative description in bureaucratic writing (Zhu, 2000). Statistics carry the connotation of accuracy and objectivity and therefore serve to support the argument as hard evidence. This sub-move plays an essential role in establishing credentials and promoting the university by citing concrete examples to prove its quality and makes it an ideal choice.

\subsubsection{Publications}

Only ZJU lists its publication house (Zhejiang University Press), newspaper (Zhejiang University Newspaper) and journal (Journal of Zhejiang University) with links to establish credentials. It is not uncommon to see university post their publication information on websites, but it is quite rare to see it in the "About Us" section. This move shows the special significance that ZJU attaches to its publication information.

As is described above, the EC move is a core component in the "About Us" section, exhibiting each university's USP via giving a brief account of its basic information, history, statistics as well as publication information to the public. A wide variety of discursive strategies have been adopted to present the university in a positive light. Such "self-presentation" or "self-appraisal" tactic is commonly used in promotional genres since they help to present "an adequately relevant, positive and credible description of the product or service and a good indication of potential value to its intended audience" (Bhatia, 1993, p. 66).

\subsection{Describing Administration}

This move is particularly devoted to introducing the leadership, administrative staff and departments of the university. As the top administrative officials in Chinese universities, i.e., presidents, vice presidents and Communist Party secretaries are appointed by the government, this move is especially significant as it fulfils the communicative purpose of demonstrating the authority and supremacy of the leadership, as is accredited and recognized by the government. In this sense, such move reflects the top Chinese universities' traditional image of gate-keeping public institutions (Zhang \& O'Hallaran, 2012). While all five universities list the name and title of the current administrators in a neutral tone, which is a common practice, individual variation does exist. For instance, THU also lists the name and tenure of former presidents, intended for the display of its long-standing history, deeply-rooted traditions as well as the eminent masters of the past generations, such as Mei Yiqi. Another prime example is that in NJU's website, a biography and a photo of the chancellor and the president are also provided, following the practice of some top universities in the world, such as MIT and Harvard. Additionally, its website finds an overview of the academic committee, the board of trustees (a corporate term) and the administrative offices with contact number of each office. Apparently, more information about NJU's governance is disclosed to the public, making it the most open and transparent website regarding this move. Such 
practices are more "conversationalized" and "personalized" (Fairclough, 1995, p. 80), as readers are given more consideration and respect in the exchange of information as well as more equality in position.

\subsection{Attracting Attention}

Osman (2008) identifies the section of "university slogan or motto" as a move of attracting reader attention in the rebranding process of Malaysian public universities. Similarly, the university logo, motto, song and video constitute the complete identity of Chinese universities. Among the five universities in the current study, only NJU and FDU have particularly designated a section called "university motto and spirit" and "identity" respectively to explain this part of information. In the case of NJU, both Chinese and English version of its motto and spirit are provided, alongside a brief account of their meanings and connotations. A distinctive feature of NJU's motto and spirit is that the eight Chinese characters “诚朴雄伟, 励学敦行” (Sincerity with Aspiration, Perseverance with Integrity) and “严谨求实, 勤奋创新” (rigorous, realistic, diligent, creative) are written in different styles of Chinese calligraphy, a clever strategy to impress the readers and attract their attention. In the case of FDU, the "identity" is comprised of five components: name, badge, motto, song and anniversary, covering the broadest scope of information. Nonetheless, such information is shown to the public in its original Chinese version (with the exception of a 61-word English account of its anniversary), virtually inaccessible to non-Chinese readers. Luckily, the authentic autograph of the university name, motto, and the manuscript of university song are on display, which to some extent compensate for the loss of English version and contribute to reinforcing the university's identity.

Other noticeable characteristics of university identity also deserve our attention. For instance, only THU has its motto “自强不息, 厚德载物” (Self-discipline and Social Commitment) inscribed in its logo, a revelation of its link to the ancient Chinese classic work "I-Ching", in which the motto originated. Meanwhile, while most university logos in China are round-shaped (four out of five in this study), the NJU's logo is made in the shape of a shield, a visually outstanding element that helps to distinguish itself from other universities. Also worth mentioning is the use of advertising video by SJTU to exhibit itself in an all-round way via the most direct and arousing media. What's more, ZJU provides an English version of its university song's lyrics. To sum up, in face of the increasingly fierce competition of higher education market, this move serves the communicative purpose of stimulating the readers' interest, leaving a deep impression on their mind and increasing the possibility of opting for the university when they are provided with a bewildering array of choices.

\subsection{Offering Extra Services}

As is mentioned above, the term "service" refers to both educational service and support service offered by university. Since educational service is the core service that a university's credentials mostly rest upon, it constitutes a major component in the university website as an independent section separate from the "About Us" section under the column heading of "Academic programs" or "Faculties". Given the limitation of our study to the "About Us" section only, we will not go into deeper discussion of educational service. While educational service is the only "straightforward move" in higher education genre, the move of offering extra service is also essential for it portrays that "good facilities produce good programs" (Osman, 2008, pp. 67-68). Besides, as Askehave suggests, universities nowadays promote "an interesting and challenging university 'experience' with 'extra' services included" (2007, p. 739). Therefore, it seems safe to say that this move is more promotional in nature, serving the communicative purpose of "selling" the university from yet a different angle.

A comparison of the five university websites shows that only SJTU has contained this move in the "About Us" section, which is split into such four sub-sections as "International Student Services", "Life@SJTU", "Library" and "Museums". For the sake of a more meaningful analysis, we have broadened the scope of this move to include any expressions concerning "extra services" in other parts of the "About Us" section. Three marked discursive strategies have been employed to fulfill the purposes of this move:

A. describing university as service provider

- $\quad . .$. while providing top quality services, the SJTU Library pursues the service idea of ...

- This facilities its integrated and personalized services. (SJTU)

- $\quad$ No. 8, 9, 10 Dorm Building are equipped with individual bathrooms. (SJTU)

- ... the basic furniture ... and bed textiles ... are also offered for free use. (SJTU)

- Our goal is to create a tranquil campus environment that is ideal for reading and learning. (THU)

- Rich campus culture, advanced teaching facilities ... create favorable conditions for students' development. (ZJU) 
A salient feature of the above extracts is that university is invariably portrayed as the service provider, exemplified by the frequent use of service-related verbs such as "provide", "offer", "equip" and "create", the explicit description like "top quality services" and "personalized services" as well as a wide range of benefits, including facilities, environment and conditions. Such linguistic choices aim to rebrand the universities not only as academic institutions, but more importantly, as service-minded institutions where students can enjoy all forms of extra services to enrich their campus experience. This strategy bears much resemblance to the one that is frequently used in corporate advertising intended for building a customer-oriented image of a corporation.

B. using enabling clauses

- ... we have pursued deeper international cooperation in all arenas to help our students gain international perspectives. (THU)

- Tsinghua has assisted students in participating in ... (THU)

- We have made robust efforts to encourage our students to take part in ... (THU)

- The Museum brings you an opportunity to dive into the digital history of ... (SJTU)

These examples all contain enabling clauses, which is defined by Askehave as clauses with the initiator, in this case, the university, as "the provider of the possibility of doing/being something". That is to say, students are empowered to do something or become something owing to the help or opportunities given by the university. Likewise, this strategy helps build a student-centered image of a university, where the students can give their potential to full play, explore various possibilities and achieve all-round development, not only in academic performance, but also in extra-curriculum activities and personal life.

C. describing students as action takers

- ... you are allowed to move into the dorm room after Sept. $10^{\text {th }}$. Before moving into the dorm on campus, you could stay in hotel near campus for your early arrival. (SJTU)

- You can also contact Qingyun Visitor Center for the campus tour service. (FDU)

This strategy characterizes potential students as action takers who can make their own decisions in choosing and making use of the services and resources offered by the university. Similarly, these expressions intend to convey a message to the students that the universities are student-oriented and even position them as "having authority" to make free choice (Fairclough, 1993, p. 157). In this respect, SJTU has fared better than other four universities, as it not only specially designs an "International Student Services" sub-section, but also consistently describes students as action takers in the text.

\subsection{Locating the Service}

This move aims to introduce the location of the university and give directions to the campus. It has been a common practice in the tourist industry to brag the geographical location and scenery of a tourist destination, since the natural surroundings of a place constitute its most unique selling point. What interests us is the fact that these aspects have also been highlighted as promotional elements in higher educational genres such as university brochures, prospectus and advertisement for academic post to attract readers' attention (Askehave, 2007; Osman, 2008; Xiong, 2012). Consequently, it offers a new point of view to examine the marketization representation in higher education discourse.

Although all five universities provide a campus map (with photos of campus scenery in some cases) with information about the size, layout of different campuses as well as transportation services, only FDU and ZJU have an independent sub-section dedicated to this move. A study of this part shows that authorless discourse dominates the texts, with few examples of promotional discourse, two of which are shown as follows:

- There are convenient options for transportation and amenities in the area surrounding the campus. (FDU)

- Located in the historical and picturesque city of Hangzhou, Zhejiang University is a prestigious institution...

While the first example emphasizes the convenience of the university's surrounding area, the second one highlights the scenery via the evaluative adjective "picturesque" and foregrounds the location of Hangzhou, a renowned tourist city in China. Moreover, there is a special sub-section called "Hangzhou" in ZJU's website, which links to the city's official website, proof positive that ZJU has indeed used the city's positive image and fame as a USP to promote the university. 


\subsection{Soliciting Responses}

Though optional in nature, this move is also important because it invites further communication and calls for the readers to take actions by providing all crucial contact information, including the name, address, email address, telephone numbers, etc. Potential students may directly enter into contact with the university to ask for further details. Since it practically "solicits" responses from the readers, this move is perceived as a promotional strategy (Osman, 2008, p. 70).

Our study finds that although the "Visiting Fudan" sub-section is identified as the move of "locating the service", it does give out certain contact information like the "Telephone Operator" number. Meanwhile, only SJTU has a real "Contact Us" sub-section in the "About Us" section, with all necessary contact information provided in detail. Two discursive strategies have been used to achieve the promotional function of this rhetorical move in SJTU's website: the use of conditional if-clause and the imperative clause.

- If you have any suggestion and comments about our website, please fill out the form below.

- Enter your contact information and message.

While the conditional if-clause is a common advertising strategy to "appeal to the customer's interest" (Leech, 1966, p. 117), the imperative clause is "an attention-seeking advice known from promotional and advertising discourse" (Askehave, 2007, p. 736). Both strategies can maximally attract interested readers' attention and encourage them to give immediate and direct responses. SJTU has taken one step further in this move by inviting readers to fill out a form as is shown below:

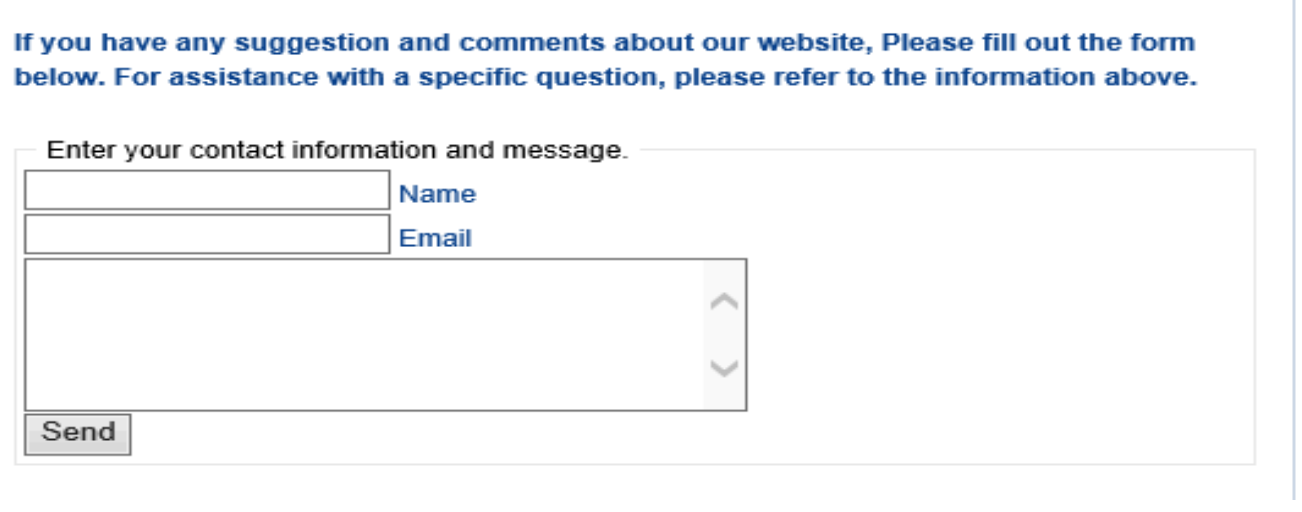

Figure 1. The form provided in the "Contact Us" sub-section in SJTU's website

This is by far the most direct means to solicit readers' responses and express the university's friendly attitude to initiate an information exchange with readers on an equal basis, a noticeable sign of conversational discourse.

\section{Conclusion}

The marketization trend has indeed brought about profound changes to all arenas of society in this globalized age, including the higher educational sector in China. While universities are picking out the best students from the pool of candidates, students are also choosing their ideal universities, with more options in today's higher education market. In order to stand out in this two-way selection process, universities have enthusiastically embraced the corporate advertising strategy to promote themselves to win over the inclined and half-inclined students. At the discourse level, such marketization trend is evident in various higher education genres. Therefore, the present discursive study has specially examined the effect of marketization on the university website homepage as a genre, with a particular focus on the "About Us" section. Major findings in response to the research questions can be summarized as follows.

Firstly, there are primarily three communicative purposes of the "About Us" section in the five university website homepages: welcoming, informing and promoting, which are fulfilled by seven rhetorical moves: welcoming, establishing credentials, describing administration, attracting attention, offering extra services, locating the service and soliciting responses. While establishing credentials and describing administration are obligatory moves and contained by all universities, the other five are optional, existent in some but not all universities. Secondly, a wide variety of discursive strategies have been adopted to achieve these communicative 
purposes. Generally speaking, there is "an intertextual mix" (Xiong, 2012, p. 331) or "hybridization" (Han, 2014, p. 99) of both authoritative discourse and conversational discourse in this genre. On the one hand, the authoritative discourse dominates the texts, reflecting the centralized system and instrumental operation of Chinese university. Such discourse elevates the universities to hierarchical authority and positions the students as subordinates, a representation of the traditional "asymmetric relationship" (Xiong, 2012, p. 331) between the two sides. On the other hand, the conversational discourse in the president's welcoming remark and other places manifests the universities' willingness to establish an equal and friendly relationship with the students. Additionally, promotional elements in the contents like the university logo, song and video as well as in the linguistic choices like the use of qualitative and quantitative terms have been employed to attract readers' attention and "sell" the universities in the best possible way. These practices fully demonstrate that all five universities, to varying degree, have maneuvered to cope with the strong market forces.

The limitation of the current study lies in the fact that our corpus consists of only five universities in China, which reduces the generalizability of the findings to some extent. However, it contributes to understanding the marketization in higher education discourse in Chinese scenario, which is manipulated by the dual forces of bureaucracy and market (Xiong, 2012; Han, 2014). Furthermore, it broadens the scope of genre analysis to university website homepages, in addition to the more frequently researched genre of brochure and prospectus. It is suggested that future studies may be conducted on other genres of higher education and more universities could be included in the corpus. A comparative study of Chinese and foreign universities scenario is also recommended to add a cross-cultural perspective to this field.

\section{References}

Askehave, I. (2007). The impact of marketization on higher education genres: The international student prospectus as a case in point. Discourse Studies, 9(6), 723-742. https://doi.org/10.1177/1461445607082576

Askehave, I., \& Swales, J. M. (2001). Genre identification and communicative purpose: A problem and a possible solution. Applied Linguistics, 22, 195-212. https://doi.org/10.1093/applin/22.2.195

Ayoubi, R. M., \& Massoud, H. K. (2007). The Strategy of internationalization in universities: A quantitative evaluation of the intent and implementation in UK universities. International Journal of Educational Management, 21(4), 329-349. https://doi.org/10.1108/09513540710749546

Berkenkotter, C., \& Huckin, T. N. (1993). Rethinking Genre from a Socio-cognitive Perspective. Written Communication, 10(4), 475-509. https://doi.org/10.1177/0741088393010004001

Bhatia, V. K. (1993). Analysing genre: Language use in professional settings. London: Longman.

Bhatia, V. K. (2005). Generic Patterns in Promotional Discourse. In H. Halmari, \& T. Virtanen (Eds.), Persuasion across Genres: A Linguistic Approach (pp. 213-228). Amsterdam: John Benjamins. https://doi.org/10.1075/pbns.130.13bha

Brown, F. (1995). Privatization of public education: Theories and concepts. Education and Urban Society, 27(2), 114-126. https://doi.org/10.1177/0013124595027002002

Brown, R. (1997). Developing effective overseas partnerships: Future lessons from Britain. Journal of International Education, 9(3), 12-19.

Connell, I., \& Galasinski, D. (1998). Academic Mission Statements: An Exercise in Negotiation. Discourse and Society, 9(4), 457-479. https://doi.org/10.1177/0957926598009004003

Fairclough, N. (1992). Discourse and Social Change. Cambridge: Polity Press.

Fairclough, N. (1993). Critical discourse analysis and the marketisation of public discourse: The universities. Discourse and Society, 4(2), 133-168. https://doi.org/10.1177/0957926593004002002

Fairclough, N. (1995). Critical discourse analysis: The critical study of language. London: Longman.

Fairclough, N. (2001). Language and power (2nd ed.). Harlow: Longman.

Fletcher, R. (2006). The impact of culture on web site content, design, and structure: An international and a multicultural perspective. Journal of Communication Management, 10(3), 259-273. https://doi.org/10.1108/13632540610681158

Fudan University. (2017). About Fudan. Retrieved from http://www.fudan.edu.cn/en/channels/view/34/

Han, Z. R. (2014). The marketization of public discourse: The Chinese universities. Discourse \& Communication, 8(1), 85-103. https://doi.org/10.1177/1750481313503221 
Jarvis, P. (2001). Universities and Corporate Universities. London: Kogan Page.

Jordan, M. P. (1986). Co-associative lexical cohesion in promotional literature. Journal of Technical Writing and Communication, 6, 33-53. https://doi.org/10.2190/B2T3-9P7J-TD84-7X7D

Kong, K. C. C. (2006). Property Transaction Report: News, Advertisement or a New Genre? Discourse Studies, 8(6), 771-796. https://doi.org/10.1177/1461445606069329

Kwong, J. (2000). Introduction: Marketization and Privatization in Education. International Journal of Educational Development, 20, 87-92. https://doi.org/10.1016/S0738-0593(99)00060-7

Leech, G. N. (1966). English in advertising: A linguistic study of advertising in Great Britain. London: Longman.

Li, J. (2011). Change Chinese returnee rules. Nature, 474, 285. https://doi.org/10.1038/474285d

Mazzarol, T. (1998). Critical success factors for international education marketing. International Journal of Educational Management, 12(4), 163-175. https://doi.org/10.1108/09513549810220623

Mok, K. H. (1999). Education and the market place in Hong Kong and Mainland China. Higher Education, 37, 133-158. https://doi.org/10.1023/A:1003542916506

Mok, K. H. (2000). Marketizing higher education in post-Mao China. International Journal of Educational Development, 20, 109-126. https://doi.org/10.1016/S0738-0593(99)00062-0

Muhlhausler, P., \& Harre, R. (1990). Pronouns and people: The linguistic construction of social and personal identity. Oxford: Basil Blackwell.

Nanjing University. (2017). About. Retrieved from https://www.nju.edu.cn/EN/wbout/main.htm

Osman, H. (2008). Re-branding academic institutions with corporate advertising: A genre perspective. Discourse \& Communication, 2(1), 57-77. https://doi.org/10.1177/1750481307085577

QS World University Rankings 2018. (2018). Retrieved from https://www.topuniversities.com/university-rankings/world-university-rankings/2018

Shanghai Jiaotong University. (2017). About SJTU. Retrieved from http://en.sjtu.edu.cn/about-sjtu/overview

Swales, J. (1990). Genre analysis: English in academic and research settings. Cambridge: Cambridge University Press.

Swales, J. (2004). Research genres-exploration and application. Cambridge: Cambridge University Press. https://doi.org/10.1017/CBO9781139524827

Symes, C. (1996). Selling futures: A new image for Australian universities? Studies in Higher Education, 21, 133-147. https://doi.org/10.1080/03075079612331381318

Tsinghua University. (2017). About TH. Retrieved from http://www.tsinghua.edu.cn/publish/newthuen/newthuen_cnt/about-th/index.html

Wang, M. (2016). Multimodal Discourse Analysis on the Representation of Social Actors on Homepages of Tsinghua University and Stanford University (Dissertation for the Degree of Master). Chang'an University.

Wernick, A. (1991). Promotional Culture: Advertising, Ideology and Symbolic Expression (Theory, Culture \& Society). London: Sage. https://doi.org/10.1007/978-1-349-22346-6_17

Xiong, T. (2012). Discourse and marketization of higher education in China: The genre of advertisements for academic posts. Discourse \& Society, 23(3), 318-337. https://doi.org/10.1177/0957926511433786

Zhang, Y. Q., \& O'Halloran, K. L. (2012). The gate of the gateway: A hypermodal approach to university homepages. Semiotica, 190, 87-109. https://doi.org/10.1515/sem-2012-0041

Zhejiang University. (2017). About. Retrieved from http://www.zju.edu.cn/english/wbout/list.htm

Zhu, Y. (2000). Structural moves reflected in English and Chinese sales letters. Discourse Studies, 2, 473-496. https://doi.org/10.1177/1461445600002004004 


\section{Copyrights}

Copyright for this article is retained by the author(s), with first publication rights granted to the journal.

This is an open-access article distributed under the terms and conditions of the Creative Commons Attribution license (http://creativecommons.org/licenses/by/4.0/). 